\title{
Problematika Guru Di Madrasah Dalam Perspektif Supervisi Pendidikan
}

\author{
Nurkholis \\ Universitas Islam Negeri Raden Fatah Palembang \\ E-mail: nurkholisslamet1968@gmail.com
}

\begin{abstract}
The quality of educators can be seen from their level of professionalism in realizing everything related to the teaching assignment of students. They generally find it difficult to carry out learning innovations in their Madrasahs. The teachers also experienced many obstacles in the implementation of supervision because the implementation only touched the administrative aspect, not professional development. Departing from this premise, the authors are interested in conducting research with a survey approach regarding the problems of teachers in madrasas (State MTs in Palembang City) in planning, implementing and evaluating learning.
\end{abstract}

Keywords: Madrasah, Teacher Probelamatika and Educational Supervision

\section{Pendahuluan}

Guru merupakan komponen paling menentukan dalam sistem pendidikan secara keseluruhan, yang harus mendapat perhatian sentral, pertama, dan utama. Figur yang satu ini akan senantiasa menjadi sorotan strategis ketika berbicara masalah pendidikan, karena guru selalu terkait dengan komponen manapun dalam sistem pendidikan. Guru memegang peran utama dalam pembangunan pendidikan, khususnya yang diselenggarakan secara formal di Sekolah/Madrasah. Guru juga sangat menentukan keberhasilan peserta didik, terutama dalam kaitannya dengan proses belajar mengajar. Guru merupakan pemegang peranan utama dalam proses belajar mengajar. Proses belajar mengajar merupakan suatu proses yang mengandung serangkaian perbuatan guru dan peserta didik atau dasar hubungan timbal balik yang berlangsung dalam situasi edukatif untuk mencapai tujuan tertentu (Sabri, 2005:20).

Dalam Islam, guru (pendidik) juga merupakan figur yang sangat penting, begitu pentingnya seorang pendidik sehingga menempatkan kedudukan pendidik setingkat di bawah kedudukan nabi dan rasul. Maka dalam pendidikan Islam, pendidik adalah komponen yang sangat penting dalam sistem kependidikan, karena ia yang mengantarkan peserta didik pada tujuan yang telah ditentukan, bersama komponen yang lain terkait dan lebih bersifat komprehensif. Peranan pendidik dalam menunjang keberhasilan pendidikan sangat penting. Karena itu, upaya apapun untuk meningkatkan mutu pendidikan harus bersentuhan dengan sumber daya guru atau pendidik (Ramayulis, 2006:32).

Keberadaan pendidik dalam dunia pendidikan sangat krusial, sebab kewajibannya tidak hanya mentransformasikan pengetahuan (knowledge) tetapi juga dituntut menginternalisasikan nilai-nilai (value/qimah) pada peserta didik. Bentuk nilai yang 
diinternalisasikan paling tidak meliputi: nilai etis, nilai pragmatis, nilai effect sensorik dan nilai religious (Ahmad Tafsir, 2005:24). Pendidik dalam Islam adalah orang-orang yang bertanggung jawab terhadap perkembangan peserta didik dengan mengupayakan perkembangan seluruh potensi peserta didik, baik potensi afektif, potensi kognitif maupun potensi psikomotorik. Pendidik sebagai faktor yang menentukan mutu pendidikan. Karena pendidik berhadapan langsung dengan para peserta didik dalam proses pembelajaran di kelas. Di tangan pendidik mutu kepribadian mereka dibentuk (Ahmad Tafsir, 2005:24).

Guru adalah kurikulum berjalan. Sebaik apa kurikulum dan sistem pendidikan yang ada, tanpa didukung kemampuan guru, semuanya akan sia-sia. Guru kompeten dan efektif, tanggung jawab utamanya mengawal perkembangan peserta didik sampai suatu titik maksimal. Tujuan akhir seluruh proses pendampingan guru adalah tumbuhnya pribadi dewasa yang utuh. Tanpa guru kurikulum itu hanyalah benda mati yang tiada berarti (Mulyasa, 2007:19).

Dalam pendidikan, pendidik mempunyai tugas ganda, yaitu sebagai abdi negara dan abdi masyarakat. Sebagai abdi negara, pendidik dituntut melaksanakan tugas-tugas yang menjadi kebijakan pemerintah dalam usaha mencerdaskan kehidupan bangsa. Dan sebagai abdi masyarakat, pendidik dituntut berperan aktif mendidik masyarakat dari belenggu keterbelakangan menuju masa depan yang gemilang. Dan untuk dapat melaksanakan hal itu semua seorang pendidik harus memenuhi persyaratan dan kompetensi juga profesional. Kompetensi dasar (basic competency) bagi pendidik ditentukan oleh tingkat kepekaannya dari bobot potensi dasar dan kecenderungan yang dimilikinya (Mulyasa, 2007:19).

\section{Problema Guru Madrasah dalam Ketrampilan Mengajar}

Bertolak dari kompetensi guru yang harus dimiliki oleh guru dan adanya keinginan kuat untuk menjadi seorang guru yang baik, persoalan guru di Sekolah/Madrasah terus menarik untuk dibicarakan, didiskusikan, dan menuntut untuk dipecahkan. Dalam hal ini adalah masalah yang berkaitan dengan ketrampilan mengajar guru, masalah tersebut secara langsung akan berpengaruh terhadap proses belajar mengajar di kelas.

Guru hidup dalam situasi yang selalu berubah. Pribadi manusia adalah keunikan yang sukar diduga. Sering terjadi faktor manusia yaitu ketidak mampuan manusia yang sebenarnya ia sadar bahwa sesuatu yang baik itu dapat ia kerjakan, tetapi justru yang ia inginkan itu tidak ia kerjakan tetapi kelemahan yang tidak ia inginkan itulah yang sering ia kerjakan. Semua guru mau memperbaiki profesi mengajarnya, tetapi seolah-olah ia mengalami banyak problem pribadi (personal problem) maupun problema jabatan (profesional problem). Memang tiap guru mempunyai perbedaan pribadi.

Walaupun semua unsur-unsur pokok dalam proses belajar mengajar sudah diungkapkan dan guru-guru sudah memiliki pengetahuan dan ketrampilan dalam usaha memperbaiki pengajaran, namun masih ada masalah-masalah yang perlu dipelajari lebih dalam usaha meningkatkan mutu pelajaran. Masalah tersebut seperti masalah dalam merumuskan tujuan, masalah dalam memilih metode mengajar, masalah dalam menggunakan sumber belajar, masalah dalam membuat dan menggunakan alat peraga, masalah dalam 
merencanakan program pengajaran dan masalah dalam merencanakan dan melaksanakan evaluasi (Nazarudin, 2018:22-32).

\section{Masalah dalam merumuskan tujuan}

Tujuan pembelajaran bukan sekedar rumusan dengan kata-kata yang indah, tetapi harus dapat menjawab masalah pokok terkait dengan konsep yang ideal yang menjadi tujuan dan pandangan hidup masyarakat. Dalam proses belajar mengajar, kadang-kadang guru tidak memiliki tujuan yang jelas. Guru mengajar hanya berdasarkan apa yang tertuang di dalam buku paket. Tujuan hanya mencakup salah satu domain saja, yakni aspek kognitif saja. Begitu juga masih banyak guru yang belum bisa merumuskan tujuan pembelajaran, sehingga rumusan tujuan terkesan bukan tujuan siswa tetapi tujuan guru. Jika dihadapkan pada guru-guru yang demikian, maka jelas mereka memerlukan bantuan dengan supervisi.

\section{Masalah dalam memilih metode mengajar}

Metode adalah alat komunikasi antara guru dan murid pada waktu belajar. Komunikasi itu terjadi melalui penerapan panca indra. Banyak metode yang dapat dipilih oleh guru untuk digunakan sebagai alat komunikasi belajar mengajar, diantaranya adalah ceramah, tanya jawab, diskusi, pemberian tugas, demonstrasi, kerja kelompok, pemecahan masalah, karya wisata, simulasi, bermain peran, studi kasus dan inkuiri. Untuk menerapkan dan memilih metode-metode tersebut, guru berpegang pada keyakinan bahwa dengan metode yang dipilih, tujuan belajar dapat tercapai secara maksimal. Oleh karena itu, guru dapat mengkombinasikan beberapa metode untuk diterapkan dalam satu paket pembelajaran. Namun kenyataan yang terjadi masih banyak guru yang mendominasi kegiatan belajar dengan metode ceramah. Padahal sebagai rambu-rambu, metode ceramah hanya bisa efektif untuk digunakan sebagai metode mengajar tidak lebih dari 15 menit. Oleh karena itu, perlu untuk mengkombinasikannya dengan metodemetode yang lain.

\section{Masalah dalam menggunakan sumber belajar}

Siswa belajar dengan menggunakan sumber. Model belajar yang tradisional hanya mengandalkan pada sumber yang berasal dari guru. Sumber belajar tidaklah hanya guru. Ada banyak sumber yang dapat dimanfaatkan untuk pengalaman belajar. Sumber-sumber itu ada yang sengaja direncanakan, misalnya buku, jurnal, peta, perpustakaan dan sebagainya. Ada juga sumber yang tidak sengaja direncanakan tetapi dapat dimanfaatkan untuk kegiatan pembelajaran (lingkungan, baik fisik maupun sosial), misalnya perkebunan, sawah, sungai, masyarakat, petani, pedagang dan sebagainya.

\section{Masalah dalam membuat dan menggunakan alat peraga}

Alat peraga digunakan sebagai pembantu untuk memudahkan proses terjadinya pengalaman belajar secara maksimal. Menurut bentuknya, alat peraga dapat berupa media dua dimensi dan media tiga dimensi. Menurut fungsinya, alat peraga bisa dikelompokkan menjadi tiga, yaitu auditif, visual, dan audio visual. Guru dapat memilih dan menggunakan alat peraga tersebut dengan cara membeli maupun dengan cara membuat sendiri alat peraga yang sederhana. 


\section{Masalah dalam merencanakan program pengajaran}

Setiap guru harus membuat program pengajaran. Program pengajaran dapat disusun dan direncanakan berdasarkan waktu pelajaran. Program pengajaran hendaknya dikembangkan berdasarkan kurikulum dan ditulis dengan sistem dan format yang disepakati bersama oleh seluruh guru, sehingga memudahkan kepala Madrasah untuk melakukan pengecekan dan penilaian.

\section{Masalah dalam merencanakan dan melaksanakan evaluasi}

Untuk mengetahui keberhasilan belajar siswa, guru harus melaksanakan evaluasi proses belajar mengajar secara kontinyu. Untuk itu guru harus menyusun program dan alat evaluasi yang tepat.

\section{Problema Guru Madrasah dalam Motivasi Kerja}

Peningkatan mutu pembelajaran dan profesionalisme guru dalam kinerjanya sangat berkaitan erat dengan keefektifan layanan supervisi. Maka dari itu, diharapkan supervisor mampu mendorong guru untuk meningkatkan kualitasnya dengan peningkatan motivasi kerja guru, karena bagaimanapun motivasi kerja guru sangat berperan dalam meningkatkan kualitas dan profesionalitas guru dalam mengajar. Keefektifan supervisi di Madrasah tertentu tidak dapat dilepaskan dari tanggung jawab kepala Madrasah, karena selain sebagai pemimpin di Madrasah tersebut, kepala Madrasah juga merupakan supervisor bagi guru-guru di Madrasah tersebut.

Berbagai teknik supervisi yang dilakukan oleh kepala Madrasah, nampaknya dapat membawa dampak negatif bagi guru-guru. Hal ini sesuai dengan yang diungkapkan Olivia, sebagaimana yang dikutip Mufidah, "observasi kelas dan wawancara supervisi pada hakekatnya dapat menyebabkan berbagai bentuk kecemasan atau ketakutan terhadap guru. Bahkan dapat membawa dampak pengalaman traumatik terhadap beberapa guru". Maka dari itu, kepala Madrasah harus mampu mengadakan supervisi dengan mengembangkan teknik yang tidak menimbulkan kecemasan-kecemasan tersebut. Sehingga, disinilah hubungan interpersonal antara kepala Madrasah dengan guru memberi jalan keluar. Dengan adanya wawancara interpersonal, maka guru akan mampu melakukan perbaikan pengajaran, baik yang dapat diamati, maupun perencanaan untuk masa mendatang.

Sementara itu, sikap guru terhadap supervisi, sebagaimana kajian yang dilakukan oleh Neagley dan Evans, yang dikutip oleh Mufidah, menyatakan berbagai pernyataan, antara lain:

a. Prinsip-prinsip yang sesuai dengan perubahan sosial dan dinamika kelompok

b. Para guru menghendaki supervisi dari kepala Madrasah, sebagaimana yang seharusnya dikerjakan oleh tenaga personil yang berjabatan supervisor.

c. Kepala Madrasah tidak melakukan supervisi dengan baik.

d. Semua guru membutuhkan supervisi dan mengharapkan untuk disupervisi

e. Para guru lebih menghargai dan menilai secara positif perilaku supervisor yang hangat, saling mempercayai, bersahabat dan menghargai guru. 
f. Supervisi dianggap bermanfaat bila direncanakan dengan baik, supervisor menunjukkan sifat membantu dan menyediakan model-model pengajaran yang dipandang efektif.

g. Supervisor memberikan peran serta yang cukup tinggi kepada guru untuk pengambilan keputusan dalam wawancara supervisi.

h. Supervisor mengutamakan pengembangan ketrampilan hubungan insani, seperti halnya dengan ketrampilan teknis.

i. Supervisor seharusnya menciptakan iklim organisasional yang terbuka yang memungkinkan pemantapan hubungan yang saling menunjang.

Hasil penelitian di atas menunjukkan bahwa guru merespon dan mempunyai sikap yang terbuka terhadap supervisi. Bahkan, guru tersebut membutuhkan supervisi untuk meningkatkan kinerjanya.

Supervisi yang dilakukan oleh kepala Madrasah atau madrasah mempunyai peran untuk meningkatkan kinerja guru, terlebih lagi guru pendidikan agama Islam atau rumpunrumpunnya. Guru PAI atau lebih umumnya lagi guru pastilah mempunyai banyak masalah, karena guru mata pelajaran tersebut terlalu sibuk atau bahkan ada yang sudah tua. Maka dari itu, kinerja guru perlu ditingkatkan dengan diadakannya supervisi yang dilakukan langsung oleh kepala Madrasah.

Dalam melakukan supervisi kepada guru, kepala Madrasah atau madrasah biasanya memakai teknik wawancara atau dialog dengan guru tersebut. Dimana guru akan menjadi lebih terbuka mengemukakan masalah-masalah yang dihadapinya, lalu kemudian kepala Madrasah atau madrasah menanyakan tentang idenya untuk mengatasi masalah yang dihadapinya tersebut. Di samping itu, kepala Madrasah juga bisa mengemukakan solusi untuk guru tersebut jika hal itu diperlukan dan guru tidak dapat menemukan sendiri solusi terhadap masalahnya tersebut.

Sementara itu, supervisi dilakukan untuk meningkatkan motivasi kerja guru sehingga kinerja guru dalam mengajar juga meningkat. Kinerja yang dapat ditingkatkan adalah kinerja dalam mendesain pembelajaran dan juga kinerja dalam proses pembelajaran. Kepala Madrasah atau madrasah, sebagai supervisor harus mampu memahami permasalahan yang dihadapi oleh guru, baik dalam mendesain pembelajaran ataupun ketika proses pembelajaran. Kepala Madrasah atau madrasah hendaknya mampu memberikan solusi atau membicarakan solusi atas permasalahan yang dihadapi oleh guru tersebut secara bersama-sama antara supervisor dengan guru tersebut.

Dalam mengadakan supervisi, biasanya kepala Madrasah juga menerapkan teknik kelompok, yaitu dengan rapat dan juga workshop atau seminar. Namun biasanya teknik ini tidak hanya diperuntukkan untuk guru satu bidang studi saja, melainkan seluruh guru yang ada di Madrasah tersebut. Guru mestinya menyadari bahwa dengan adanya supervisi, maka kualitas dan kuantitas kinerjanya dapat ditingkatkan. Oleh karena itu, guru mestinya sangat terbuka dalam menerima supervisi. Namun yang terjadi adalah sebaliknya, yaitu guru menutup diri dari pelaksanaan supervisi atau bahkan guru takut dengan adanya supervisi tersebut. 
Guru atau pendidik yang ideal dan profesional adalah guru atau pendidik yang siap disupervisi kapanpun, dimanapun dan oleh siapapun. Guru siap menerima kritik yang datang kepadanya, baik dari seorang siswa maupun dari teman sejawat dan pengarahan dari seorang supervisor untuk membenahi atau melengkapi kekurangan yang ada dalam dirinya. Karena setiap manusia pastilah mempunyai kekurangan, dan semakin profesional seorang manusia tentulah ia semakin menyadari dan berusaha menutupi kekurangannya tersebut.

Guru atau pendidik yang ideal harus mempunyai berbagai pengetahuan sebagaimana yang penulis kemukakan pada bab-bab sebelumnya dan juga menjadi sosok idola di depan anak didiknya. Di samping itu, guru atau pendidik zaman sekarang juga harus memiliki sertifikasi atau penghargaan keprofesionalisasiannya dan juga siap untuk disupervisi ketika sedang melakukan pembelajaran, dimanapun, kapanpun dan oleh siapapun.

\section{Problema Guru Madrasah dalam Kepuasan Kerja}

Supervisi terhadap guru salah satu tujuannya adalah untuk membina dan membantu guru dalam mengatasi berbagai masalah yang dialaminya sehingga dapat meningkatkan kualitas guru dalam bekerja. Selain itu, juga bertujuan untuk memberikan kepuasan terhadap guru karena masalah-masalah yang dihadapinya dapat terpecahkan. Oleh karena itu, tugas seorang supervisor dan juga supervisee (guru) untuk saling bekerja sama sehingga kepuasan kerja itu dapat terwujud.

\section{Membantu Guru-Guru Yang Belum Berpengalaman}

Kebanyakan guru belum berpengalaman. Hal ini merupakan tantangan bagi supervisor. Ciri-ciri guru yang belum berpengalaman, adalah pemalu, canggung dalam pergaulan dengan teman sejawat, dan tidak merasa aman dalam melaksanakan tugas. Mereka berharap mendapatkan pelayanan dan pendekatan dari orang yang lebih berpengalaman.

Bantuan yang dapat diberikan kepada guru tersebut antara lain: 1) membantu memecahkan problema yang dihadapi; dalam mengajar dan merencanakan tugas-tugas mengajar, 2) membantu mereka untuk mengenal murid-murid dan dapat mengidentifikasikan diri dengan murid. Identifikasi ini sering keliru. Seri guru baru menyangka mengidentifikasi diri dengan murid, berarti bergaul seperti teman murid dan berlaku sebagai murid. Identifikasi seperti itu mengakibatkan pribadi guru lebur dan hilanglah wibawanya, 3) mengantarkan guru baru ke dalam suasana pergaulan antar guru.

Teknik yang paling tepat untuk membantu guru adalah program orientasi percakapan pribadi atau mengikut sertakan dalam panitia kerja atau kelompok diskusi. Bimbingan dan pengarahan yang tepat akan sangat membantu pertumbuhan guru baru. Namun perlu diperhatikan bagi seorang supervisor, bahwa perhatian atau perlakuan terhadap seorang guru juga harus mempertimbangkan guru-guru yang lain, agar tidak menimbulkan rasa iri. Maka dari itu, kepala Madrasah sebagai seorang supervisor juga harus bisa berbuat adil kepada bawahannya dan dalam membina guru yang baru dan belum berpengalaman tidak boleh mengabaikan guru-guru yang sudah ada. Tanpa sikap dan sifat adil, maka ketimpangan dan kecemburuan akan selalu terjadi.

\section{Membantu Guru-Guru yang Sedia Membantu Guru yang Tidak Hadir}


Salah satu masalah yang sering dihadapi kepala Madrasah ialah masalah guru yang tidak hadir pada jam pelajaran yang ditentukan. Pada saat sekarang ini biasanya sebab-sebab ketidakhadiran itu bermacam-macam, misalnya karena sakit, halangan-halangan di rumah tangga, tugas-tugas tambahan di luar Madrasah, cuti hamil dan sebagainya. Dalam hal ini harus ada kesediaan dan kerelaan dari rekan guru lain untuk mengisi kekosongan itu. Sistem yang sering dipakai adalah sistem piket. Tetapi yang terpenting dalam hal ini ialah penciptaan Madrasah yang menyenangkan di mana semua guru merasa saling membantu, tidak ada masalah mengenai waktu-waktu yang kosong.

Di samping itu, kepala Madrasah juga harus memberikan motivasi kepada guru yang sering tidak hadir dan juga guru pengganti agar selalu saling membantu dan saling mengisi. Menurut Mulyasa "motivasi merupakan salah satu faktor yang turut menentukan keefektifan kerja". Maka tanpa motivasi dari kepala Madrasah, dorongan untuk giat bekerja tidak ada dan kinerja guru akan semakin tidak efektif, sehingga mutu pendidikan sulit untuk ditingkatkan.

\section{Membantu Guru-Guru Yang Bekerja Kurang Efektif}

Sebagaimana manusia, tentu setiap guru mempunyai kelemahan-kelemahan tersendiri. Guru yang mempunyai kelemahan, biasanya menutup dirinya bila ia bersifat introvert. Tetapi ada juga menutupi kelemahan dirinya dengan mengadakan manipulasi tingkah laku, misalnya menarik perhatian orang lain dan bertindak yang menyimpang. Itu terletak pada latihan kebiasaan dan disiplin yang kurang. Ada juga karena ia sendiri kurang pandai waktu belajar di pendidikan guru, kurang cakap mengajar, acuh tak acuh dalam membuat persiapan dan perencanaan tugas-tugas. Mungkin juga oleh karena sukar untuk menyesuaikan diri di rumah atau di masyarakat. Ada pula sebab-sebab bersumber pada emosi, misalnya ketakutan akan kegagalan, merasa tidak aman, tertekan dalam pekerjaan atau terlalu banyak diberi tugas tambahan, terlalu mementingkan diri sendiri.

Semua reaksi jiwa di atas sebenarnya bersumber dari kebutuhan yang tak terpenuhi. Oleh karena itu, harapan untuk memenuhi kebutuhan itu adalah suatu permulaan yang berhasil dari perjalanan seorang supervisor. Teknik yang dipakai adalah percakapan pribadi, karena hal tersebut akan membantu guru mengenal dirinya sendiri. Ketrampilan supervisor untuk menganalisa kasus-kasus kelemahan guru berdasarkan data obyektif. Berdasarkan data obyektif itu, guru dapat melihat dirinya dalam konteks relasi dengan orang lain. Hendaknya jangan memakai praktik-praktik yang bersifat tradisional, seperti rekomendasi agar guru itu dipindahkan, rekomendasi agar guru tersebut mencari pekerjaan lain, dan lain sebagainya.

Metode yang terbaik untuk membantu guru-guru demikian adalah meletakkan hubungan kemanusiaan yang baik, di mana ada saling percaya, saling mengakui, saling menghargai dan saling dapat bekerja sama. Dalam percakapan pribadi, supervisor dapat menimbulkan kepercayaan pada diri sendiri. Orang harus dilatih melihat self concept, konsep tentang dirinya sendiri, ide tentang dirinya. Tugas supervisor adalah memberi kebebasan agar guru dapat menemukan dirinya sendiri. Di samping percakapan pribadi, diskusi bersama, maka intervisitation juga merupakan salah satu teknik yang dapat dilaksanakan. Bagi mereka yang sukar melihat kekurangan dirinya, biasanya dapat belajar dari orang lain. 
Untuk menumbuhkan konsep diri, kepala Madrasah disarankan bersikap empati, menerima, hangat, dan terbuka, sehingga para tenaga kependidikan dapat mengekplorasikan pikiran dan perasaannya dalam memecahkan masalahnya. Jika kepala Madrasah bersikap keras dan tertutup, maka guru atau tenaga kependidikan yang lain, akan malah lari menjauhinya.

\section{Membantu Guru-Guru yang Superior}

Guru superior maksudnya guru yang sangat berhasil dalam pelajarannya karena menggunakan cara-cara mengajar yang sesuai dengan kepribadiannya atau dapat diartikan guru yang menggunakan cara-cara yang bermacam secara baik dan berhasil. Biasanya guru yang berhasil baik ini, dipilih sebagai contoh untuk ditiru. Dengan demikian mereka merasa superior.

Guru yang seperti ini hendaknya memperoleh penghargaan, namun jangan diberikan secara langsung, agar tidak menandakan bahwa guru tersebut mendapat pujian. Cara yang lain untuk memberi hadiah adalah dengan memberi tambahan gaji extra, dan lain sebagainya. Dan untuk menghilangkan rasa iri atas dirinya, maka guru-guru yang lain juga diikutkan dalam penilaian supaya lebih obyektif.

Selain itu, kunjungan terhadap guru-guru yang superior akan memberi arti tersendiri. Karena kunjungan yang dilakukan oleh supervisor akan memberi motivasi tersendiri agar guru yang superior tersebut lebih meningkatkan keprofesionalisasiannya. Di samping itu, bagi supervisor juga dapat belajar dari guru yang superior tersebut.

Guru superior adalah guru yang profesional, maka pendekatan yang digunakan adalah pendekatan non direktif. Perilaku supervisor adalah mendengarkan, memberanikan, menjelaskan, menyajikan dan memecahkan masalah. Sedangkan teknik yang diterapkan adalah dialog dan mendengarkan aktif. Jadi kepala Madrasah hanya mendengarkan dan bahkan belajar dari guru tersebut.

\section{Membantu Guru-Guru Yang Mempunyai Kelemahan Pribadi}

Salah satu kelemahan mengajar adalah kelemahan pada pribadi guru. Manifestasi kelemahan tersebut tampak pada:

a. Gangguan pada suara pada saat berkata-kata misalnya menelan kata-kata, waktu berbicara kurang jelas, suara terlalu lemah, terlalu cepat berbicara dan lain sebagainya.

b. Gangguan dalam gaya lahiriah dan inti pribadi, misalnya berpakaian terlalu mencolok dan bersolek yang berlebihan atau bahkan terlalu cerewet.

c. Gangguan watak dan pribadi, misalnya lekas tersinggung, terlalu peka, tidak percaya dan salah pengertian, dan lain sebagainya.

Supervisor dapat menerapkan cara-cara misalnya visitation oleh supervisor agar guru dapat melihat kelemahan dirinya, berdiskusi secara terus terang, atau mungkin dengan menggunakan gangguan tape recorde, agar guru biasa menghadapi gangguan. Tugas supervisor dalam hal ini ialah selalu belajar mengenal pribadi dari seluruh guru agar mampu memberi diagnosa yang tepat dan juga pembinaan kepada guru-guru.

\section{Membantu Guru-Guru yang Kurang Rajin}


Guru sering menunjukkan kemalasan, karena tidak ada penghargaan dari kepala Madrasah terhadap pekerjaan yang dilakukannya, tidak diikut sertakan dalam segala kegiatan di Madrasah, tidak ada kepercayaan dari pimpinan Madrasah, tidak mendapat perlakuan yang layak dalam hal promosi. Di samping itu, biasanya juga dipengaruhi oleh permasalahan rumah tangga dan ekonomi yang dihadapinya.

Ciri-ciri guru yang kurang rajin ini antara lain: tidak tertarik terhadap hal-hal yang baru dalam bidang pengembangan pendidikan, tidak pernah membuat catatan persiapan untuk menyajikan pelajaran, tidak pernah mengoreksi pekerjaan murid, menghindari kerja sama dengan orang lain dan cepat-cepat pulang setelah pelajaran.

Maka supervisor haru memberikan bantuan yang berupa hal-hal yang bersifat membangun, misalnya: memberi tanggung jawab kepada guru-guru, memberi kesempatan kepada guru-guru untuk menghayati motivasi dan stimulasi dengan menggunakan teknik-teknik dinamika kelompok, dan mengikut sertakan guru-guru tersebut dalam panitia kerja.

\section{Membantu Guru-Guru yang Kurang Bergairah}

Guru yang kurang bergairah mempunyai ciri-ciri antara lain: jarang tersenyum, kurang humor, kurang ramah-tamah, sukar bergaul dengan orang lain, dan seterusnya. Maka dari itu, supervisor harus selalu membawa mereka dalam suasana kegiatan yang terus menerus, memberi penjelasan dan informasi terhadap mereka tentang segala kebijaksanaan dan surat-surat edaran dari Madrasah, dan bila terjadi diskusi dan didalamnya debat tidak diambil kesimpulan, maka diskusi dapat terjadi berlarut-larut dan akan menambah ketegangan dan pertentangan saja.

Motivasi juga harus diberikan oleh kepala Madrasah kepada guru yang berada dalam keadaan demikian ini. Di samping itu, guru tersebut hendaknya diberi tugas atau beban untuk melakukan suatu pekerjaan yang agak menantang dan apabila berhasil diberi reward.

\section{Membantu Guru-Guru yang Kurang Demokratis}

Ciri guru yang kurang demokratis adalah: menolak tanggung jawab bersama, kurang senang pada orang yang bebas mengeluarkan pendapat, mengajar hanya bersifat memberitahukan dan routine, dan terhadap pimpinan hanya meminta untuk menyetujui pendapatnya saja.

Terhadap guru yang seperti ini, kepala Madrasah sebagai supervisor sebelum memberi bantuan kepada mereka, terlebih dahulu penulis sarankan untuk melakukan analisa terhadap kepemimpinan yang dilakukan selama ini. Maka berdasarkan hasil analisa tersebut, kepala Madrasah memberi motivasi kepada guru tersebut antara lain dengan cara sebagai berikut: 1) mengikut sertakan anggota staf dalam menyusun program kerja Madrasah, 2) menghargai pendapat anggota staf baik dalam rapat maupun di luar rapat, 3) mengajak anggota staf memecahkan problema yang dihadapi oleh Madrasah. 4) mengajak guru-guru untuk bersama-sama mengevaluasi program pendidikan yang ada di Madrasah tersebut.

\section{Membantu Guru-Guru yang Selalu Menentang}


Dalam suatu Madrasah, terdapat guru yang selalu tidak setuju dan selalu menentang ide yang dikeluarkan atau dikemukakan oleh kepala Madrasah, baik secara langsung maupun tidak langsung. Pertentangan ini disebabkan berbagai macam hal. Kadang ada benarnya jika guru tidak setuju dengan pendapat kepala Madrasah, hanya cara penyampaian pendapatnya dengan cara-cara yang tidak wajar.

Oleh karena itu, kepala Madrasah harus segera menyadari hal itu dan segera berusaha untuk mengatasinya. Hal yang pertama dilakukan adalah instrospeksi diri. Setelah itu, kepala Madrasah berusaha mengatasi permasalahan tersebut dengan melakukan beberapa hal ini: 1) menciptakan hubungan kerjasama dengan guru-guru tersebut dalam segala kegiatan Madrasah, 2) menciptakan suasana kerja sehingga orang merasa bahwa ia ikut menyumbangkan usaha ke arah perbaikan, 3) mengakui bahwa di luar diri, ada orang lain yang ingin bekerja dan mau membantu.

\section{Membantu Guru-Guru yang Terlalu Lama Bekerja Routine}

Kebanyakan guru-guru yang sudah lama bekerja merasa puas dengan pengalaman yang diperolehnya dan ini dianggap suatu hal yang terbaik yang pernah ia lakukan dan berlangsung selama bertahun-tahun. Walaupun di mata publik yang dilakukan oleh guru tersebut merupakan hal yang sudah tidak masanya lagi. Namun mereka sudah menganggap apa dikerjakannya tersebut merupakan hal yang cukup. Tidak ada usaha ke arah perbaikan, bahkan guru sinis terhadap perkembangan dan perubahan yang terjadi. Kurang terbuka dan sensitif terhadap pembaharuan.

Maka kepala Madrasah, sebagai supervisor harus merubah cara menatar guru. Mereka dibuat dan diberi pengertian agar menyadari bahwa mereka mengalami perubahan dan profesinya tersebut selalu berkembang. Maka mereka juga harus mengembangkan diri mereka sesuai dengan tuntutan profesi. Guru yang seperti ini, memang sulit untuk dirubah, namun jika dilakukan dengan perlahan dan ulet maka juga akan berhasil.

\section{Membantu Guru-Guru yang Menghadapi Keruwetan dalam Masalah Disiplin}

Guru ada kalanya yang mengalami kesulitan dalam melaksanakan disiplin kelas, sehingga ia mencurahkan sebagian besar waktunya untuk memikirkan cara menerapkan disiplin yang tepat bagi muridnya. Biasanya guru yang demikian, memulai pelajarannya dengan ceramah dan menghendaki agar muridnya disiplin. Sehingga sering berlaku keras dan memarahi murid-muridnya. Dan muridpun biasanya malah menentang guru tersebut dengan keras.

Permasalahan ini hanya dapat diselesaikan bila dicari dan ditemukan penyebab hal tersebut, misalnya guru kurang memiliki ketrampilan berkomunikasi, atau mungkin terdapat masalah pribadi dalam diri guru tersebut. Sehingga guru akan kehilangan rasa saling percaya. Maka guru yang demikian dapat dibantu dengan cara mengembalikan kewibawaan dan rasa saling percayanya. Caranya ialah memberi tugas dan tanggung jawab untuk melaksanakan sesuatu dengan bimbingan dan pembinaan yang bijaksana.

\section{Referensi}

Mulyasa, E., Standar Kompetensi dan Sertifikasi Guru, Bandung: PT Remaja Rosdakarya, 2007. 
Sabri, Ahmad, Strategi Belajar Mengajar dan Micro Teaching, Jakarta: Quantum Teaching, 2005.

Ramayulis, Ilmu Pendidikan Islam, Jakarta: Kalam Mulia, 2006.

Tafsir, Ahmad, Ilmu Pendidikan dalam Perspektif Islam, Bandung: Remaja Rosda Karya, 1972.

Sulistiyorini, Manajemen Pendidikan Islam, Surabaya: eLKAF, 2006.

Rohmad, Ali, Kapita Selekta Pendidikan, Jakarta: Bina Ilmu, 2005.

Mujib, Abdul, Jusuf Mudzakkir, Ilmu Pendidikan Islam, Jakarta: Kencana Prenada Media, 2006.

Mantja, Bahan Ajar Model Pembinaan/Supervisi Pengajaran (MPD530): Bagi Program S-2 Manajemen Pendidikan PPS UM, Malang: Bahan ajar tidak diterbitkan, 2000.

Mufidah, Lukluk Nur, Supervisi Pendidikan, Jember: Center for Society Studies, 2008.

Nazarudin, Problem Belajar Mengajar di Madrasah, (Yogyakata: Pustaka Felicha, 2008).

Sahertian, Piet A., Frans Mataheru, Prinsip \& Tehnik Supervisi Pendidikan, Surabaya: Usaha Nasional, tt.

Mulyasa, E., Menjadi Kepala Madrasah Profesional: Dalam Konteks Menyukseskan MBS dan KBK, Bandung: Remaja Rosdakarya, 2005.

Sahertian, Piet A., Konsep Dasar Dan Tehnik Supervisi Pendidikan: Dalam Rangka Pengembangan Sumber Daya Manusia, Jakarta: Rineka Cipta, 2000.

Arikunto, Suharsimi, Organisasi dan Administrasi Pendidikan Teknologi dan Kejuruan, Jakarta: Rajawali Pers, 1990.

Soetopo, Hendyat, Wasty Soemanto, Kepemimpinan dan Supevisi Pendidikan, Jakarta: Bina Aksara, 1984.

\section{Copyrights}

Copyright for this article is retained by the author(s), with first publication rights granted to the journal.

This is an open-access article distributed under the terms and conditions of the Creative Commons Attribution license (http://creativecommons.org/licenses/by/4.0/) 